\title{
Antifolding Activity of hsp60 Couples Protein Import into the Mitochondrial Matrix with Export to the Intermembrane Space
}

\author{
Hans Koll, * Bernard Guiard, † Joachim Rassow, * \\ Joachim Ostermann, * Arthur L. Horwich,‡ \\ Walter Neupert, " and Franz-Ulrich HartI\$ \\ *Institut für Physiologische Chemie \\ Goethestrasse 33 \\ W-8000 München 2 \\ Germany \\ tCentre de Genetique Moleculaire \\ CNRS, Universite Pierre et Marie Curie \\ 91190 Gif-sur-Yvette \\ France \\ ‡Howard Hughes Medical Institute and Department of \\ Human Genetics \\ Yale School of Medicine \\ New Haven, Connecticut 06510 \\ \$Program in Cellular Biochemistry and Biophysics \\ Rockefeller Research Laboratory \\ Sloan-Kettering Institute \\ New York, New York 10021
}

\section{Summary}

Cytochrome $b_{2}$ reaches the intermembrane space of mitochondria by transport into the matrix followed by export across the inner membrane. While in the matrix, the protein interacts with hsp60, which arrests its folding prior to export. The bacterial-type export sequence in pre-cytochrome $b_{2}$ functlons by inhibiting the ATP. dependent release of the protein from hsp60. Release for export apparently requires, in addition to ATP, the interaction of the signal sequence with a component of the export machinery in the inner membrane. Export can occur before import is complete provided that a critical length of the polypeptide chain has been translocated into the matrix. Thus, hsp60 combines two activities: catalysis of folding of proteins destined for the matrix, and maintaining proteins in an unfolded state to facilitate their channeling between the machineries for import and export across the inner membrane. Antifolding signals such as the hydrophobic export sequence in cytochrome $b_{2}$ may act as switches between these two activities.

\section{Introduction}

Mitochondria are divided into the four subcompartments: outer membrane, intermembrane space, inner membrane, and matrix, each equipped with a specific set of proteins. Most of these proteins are encoded by nuclear genes and are synthesized in the cytosol as precursors. The information for their localization in mitochondria is contained in targeting signals, mostly in positively charged, aminoterminal presequences. In addition, the precursors carry signals for their correct sorting within mitochondria (for review see Attardi and Schatz, 1988; Hartl and Neupert, 1990).
Certain pathways of intramitochondrial protein sorting have been conserved during the evolution of mitochondria from prokaryotic, endosymbiotic ancestors (Hartl and Neupert, 1990). The principle of "conservative sorting" is reflected in the biogenesis of several proteins of the inner membrane and the intermembrane space, which are first imported across both membranes into the matrix and are subsequently translocated into or across the inner membrane (Hartl et al., 1986, 1987; Mahlke et al., 1990; Stuart et al., 1990). Following import, proteins such as cytochrome $b_{2}$ or cytochrome $c_{1}$ reach the intermembrane space by an export process that resembles the main pathway of protein secretion in bacteria. The cytosolic precursors of these proteins carry bipartite amino-terminal targeting sequences. A typical positively charged presequence directing the protein into the matrix (Hurt and van Loon, 1986; Hartl et al., 1989) is followed by a targeting sequence for export that is similar to the signal sequences of bacterial and eukaryotic secretory proteins (von Heijne 1988). While the first part of the presequence is cleaved by the metal-dependent processing enzyme in the matrix (Böhni et al., 1980; Hawlitschek et al., 1988), the export sequence is removed in the intermembrane space by a mitochondrial leader peptidase (van Loon et al., 1986; Hartl et al., 1987; Schneider et al., 1991; Behrens et al., 1991).

Thus, protein targeting to the intermembrane space is a remarkably complex mechanism. Since proteins have to be maintained in an unfolded conformation for both import into mitochondria and for bacterial secretion, this raises the question of how folding is regulated in case of proteins that have to undergo successive steps of membrane translocation. Do the imported proteins fold in the matrix and have to become unfolded prior to export, or are import and export steps coupled so tightly that maintaining the protein unfolded for import would be sufficient? Translocation into the matrix is known to be dependent on the mitochondrial hsp70, Ssc1p. Such requirement has been demonstrated for cytochrome $b_{2}$ as well (Kang et al., 1990). Proteins remaining in the matrix are transferred from hsp70 to the chaperonin hsp60, which mediates their ATP-dependent folding and assembly (Cheng et al., 1989, 1990; Ostermann et al., 1989). hsp60 is the mitochondrial homolog of Escherichia coli groEL(Hemmingsen et al., 1988; Reading et al., 1989), which has recently been suggested to act as chaperone for the export of certain proteins to the periplasm (Kusakawa et al., 1989; Lecker et al., 1989; Philips and Silhavy, 1990). Previous observations with the hsp60deficient yeast mutant mif4 suggested that hsp60 may also participate in protein sorting to the intermembrane space (Cheng et al., 1989). It is unclear, however, how a function in protein export can be compatible with the established role of hsp60 in mediating protein folding.

Using specifically designed fusion proteins, we show that export can occur either concomitantly with import (when completion of import is retarded), or can follow complete translocation into the matrix. In either case, the pro- 


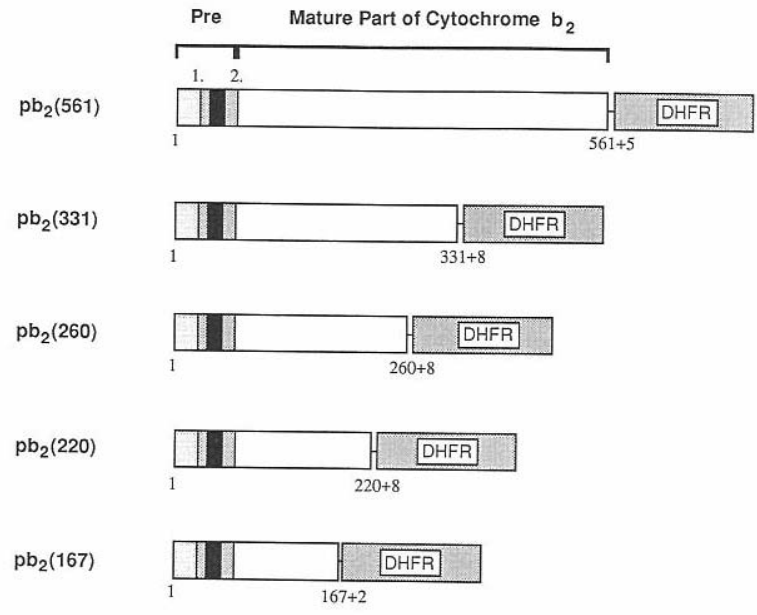

$\underbrace{\mathrm{pb}_{2}^{++} \Delta 19(167)}_{\substack{\text { RKRTQSWTAL } \\ 47}}$

Figure 1. Cytochrome $b_{2}$-DHFR Fusion Proteins

Various fusion genes encoding the $N$-terminal $167-561$ residues of the cytochrome $b_{2}$ precursor $\left(\mathrm{pb}_{2}\right)$ and the complete mouse DHFR (see Experimental Procedures) were used in a coupled transcription/translation reaction for in vitro synthesis in reticulocyte lysates and subsequent import into isolated mitochondria. The fusion proteins contain the indicated number of amino-terminal amino aclds of the cytochrome $b_{2}$ precursor (Guiard, 1985), respectively, fused by linker fragments to DHFR. The first 31 residues of the presequence are cleaved by the metal-dependent processing enzyme in the mitochondrial matrix, and the second part of 49 residues is cleaved by a peptidase located in the intermembrane space (Schneider et al., 1991). pb $2 \Delta 19$ (167)-DHFR is a derivative of $\mathrm{pb}_{2}$ (167)-DHFR lacking residues $47-65$ in the second part of the presequence of pre-cytochrome $b_{2}$, including the aminoterminal 11 residues of the 17 amino acid hydrophobic stretch extending between residues 55 and 71 (black bar). The deleted sequence is indicated.

tein traversing the matrix interacts with hsp60 and is delivered to the export apparatus in an ATP-dependent reaction. The hydrophobic export signal has a critical role in maintaining a prolonged association with hsp60, as demonstrated in binding experiments using the purified components. These observations suggest a mechanism by which hsp60 fulfills a dual role, namely as a chaperone in protein export and as a catalyst of protein folding. Similar strategies of preventing premature folding may be operative in other systems involving successive steps of membrane translocation, such as the transport of proteins from the cytosol into the thylakoids of chloroplasts, or to the outer membrane of gram-negative bacteria.

\section{Results}

Precursor Can Reach the Intermembrane Space by Spanning Three Membranes

To examine the kinetic and spatial relationship between import and export of cytochrome $b_{2}$, we analyzed the import pathways of a series of fusion proteins. These were

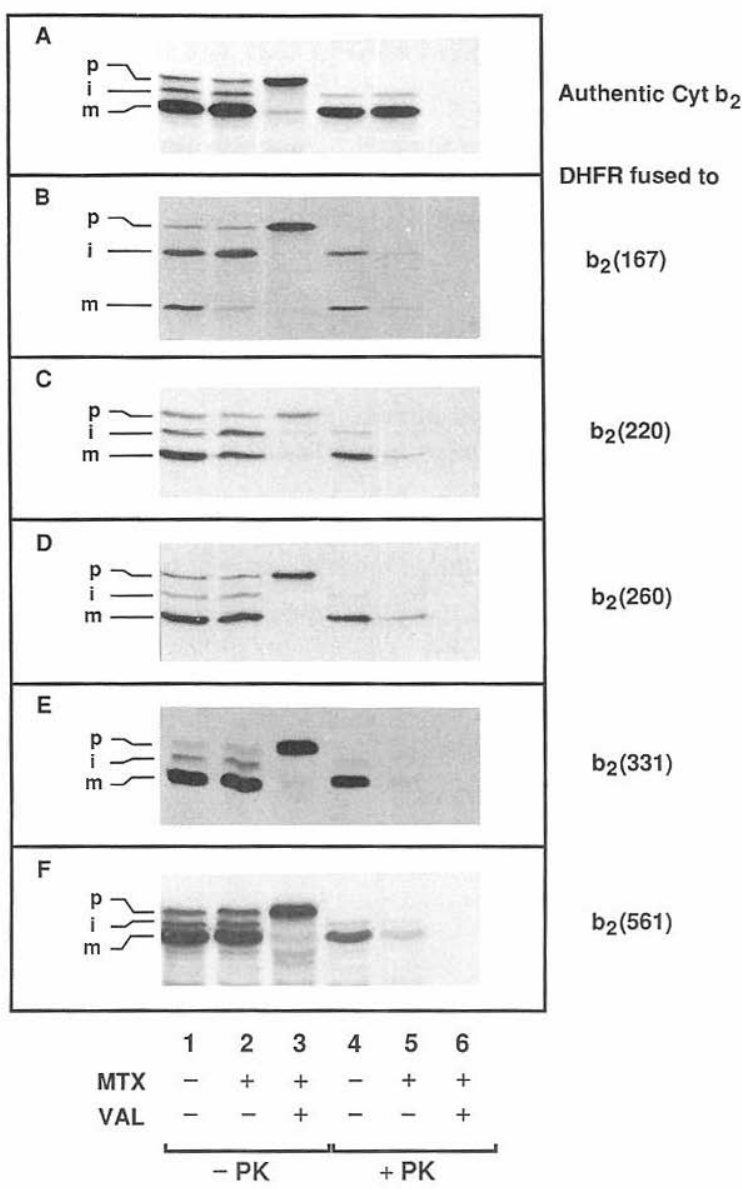

Figure 2. Translocation Intermediates of Cytochrome $b_{2}$-DHFR Fusion Proteins

Reticulocyte lysates containing [ ${ }^{35} S$ ]methionine-labeled precursors of cytochrome $b_{2}, b_{2}(167)-, b_{2}(220)-, b_{2}(260)-, b_{2}(331)$ - or $b_{2}(561)-D H F R$ were preincubated for $5 \mathrm{~min}$ at $0^{\circ} \mathrm{C}$ in $\mathrm{BSA}$ medium in the absence (lanes 1 and 4) or presence of $1 \mu \mathrm{M} \mathrm{MTX} \mathrm{(lanes} \mathrm{2,} \mathrm{3,} \mathrm{5,} \mathrm{and} \mathrm{6).} \mathrm{In} \mathrm{lanes}$ 3 and $6,1 \mu \mathrm{M}$ valinomycin (VAL) was included to inhibit the membrane potential across the inner membrane. After preincubation, the reactions were supplemented with $2 \mathrm{mM} \mathrm{NADH}$ and $0.5 \mathrm{mM} \mathrm{ATP}$. Isolated yeast mitochondria ( $60 \mu \mathrm{g}$ per reaction) were added, and incubation was carried out for $15 \mathrm{~min}$ at $25^{\circ} \mathrm{C}$. Import occured with linear kinetics for up to $20 \mathrm{~min}$ and was stopped by adding $1 \mu \mathrm{M}$ valinomycin to reactions 1 and 2 and 4 and 5 and cooling on ice. All reactions were diluted $1: 2$ by adding BSA medium (containing $1 \mu \mathrm{M}$ valinomycin and $1 \mu \mathrm{M}$ MTX as indicated). The reactlons were halved, and one portion was treated for $20 \mathrm{~min}$ at $0^{\circ} \mathrm{C}$ with $20 \mu \mathrm{g} / \mathrm{ml}$ PK (lanes 4-6), while the other was left on ice. All reactions received $1 \mathrm{mM}$ PMSF, and mitochondria were reisolated by centrifugation. After resuspending in SEM buffer and recentrifugation, the mitochondrial pellets were solubilized in SDS-containing buffer and analyzed by SDS-PAGE and fluorography. The positions of precursor $(p)$, intermediate-sized form (i), and mature form ( $\mathrm{m}$ ) are indicated.

composed of the amino-terminal residues of pre-cytochrome $b_{2}$ (1-167 up to 1-561) that were joined to the complete sequence of cytosolic, mouse dihydrofolate reductase (DHFR) (Figure 1). The fusion proteins can be arrested as translocation intermediates spanning mitochondrial contact sites when unfolding of their DHFR moiety is inhibited by binding the folate antagonist methotrexate (MTX) (Rassow et al., 1989). The radiolabeled precursor proteins synthesized in a 


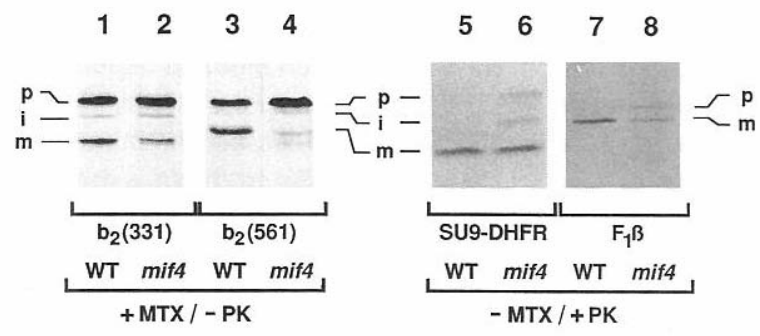

Figure 3. Requirement of hsp60 for the Processing of $b_{2}$-DHFR Fusion Proteins to the Mature Size

Isolated yeast mitochondria of wild type (WT) and hsp60-deficient mutant strain mif 4 (both grown at $37^{\circ} \mathrm{C}$ for $1 \mathrm{hr}$ ) were preincubated at $1 \mathrm{mg} /$ $\mathrm{ml}$ in BSA medium for $10 \mathrm{~min}$ at $37^{\circ} \mathrm{C}$ (nonpermissive temperature). Reticulocyte lysates, containing radiolabeled precursors of $b_{2}(331)$ DHFR (lanes 1 and 2 ) and $b_{2}$ (561)-DHFR (lanes 3 and 4) were preincubated with MTX and were added for import into mitochondria as described in Figure 2. Incubation was for $10 \mathrm{~min}$ at $37^{\circ} \mathrm{C}$. In control reactions, the import into the pretreated mitochondria of presugDHFR (lanes 5 and 6 ) and of preF1-ATPase subunit $\beta$ (F1B) (lanes 7 and 8 ) was analyzed. preSU9-DHFR is a fusion protein consisting of the presequence of the precursor of Neurospora Fo-ATPase subunit 9 (pSU9) (amino acids 1-69) and the complete mouse DHFR (Ostermann et al., 1989). (The presequence of Fo-ATPase 9 is cleaved in two steps by the matrix-localized processing enzyme [Schmidt et al., 1984]). The mitochondria in reactions 5-7 were treated with PK (+PK) as in Figure 2. Mitochondrial proteins were separated by SDS-PAGE and visualized by fluorography. The positions of precursor $(p)$, intermediate (i), and mature forms $(\mathrm{m})$ are indicated.

reticulocyte lysate were added to isolated yeast mitochondria (Figure 2). Authentic pre-cytochrome $b_{2}$ was imported and processed in two steps to the intermediate and mature forms. Most of the mature-sized protein generated was in the intermembrane space and thus protected against externally added protease (Figure 2A; Hartl et al., 1987). The various fusion proteins were also imported and processed to the intermediate and mature forms. Processing was only observed in the presence of a membrane potential across the inner membrane (Figure 2, lanes 1 vs. 3 and 4 vs. 6).

Quite unexpectedly, the precursors could reach the intermembrane space when translocation of the DHFR moiety into the matrix was blocked by adding MTX. Under these conditions, processing of the fusion proteins to the mature-sized forms was found to be dependent on the length of their mitochondrial protein parts. Maturation of $\mathrm{pb}_{2}$ (167)-DHFR to the mature size was strongly reduced while the first proteolytic cleavage to $\mathrm{ib}_{2}(167)$-DHFR was unaffected by MTX. (A small amount of mature-sized protein had escaped the block imposed by MTX and was found in a protease-protected location inside mitochondria [Figure 2B].) In contrast, with $\mathrm{pb}_{2}$ (220)-DHFR, considerable amounts of protease-sensitive, i.e., incompletely translocated, mature protein accumulated in the presence of MTX (Figure $2 \mathrm{C}$ ). The precursors containing 260-561 residues of pre-cytochrome $b_{2}$ were processed to their mature size with undiminished efficiency in spite of the presence of MTX. As expected, the processed species generated in the presence of MTX represented proteaseaccessible translocation intermediates (Rassow et al., 1989) (see below; Figure 4A). These intermediates were able to complete translocation when MTX was removed (by isolating the mitochondria and resuspending them in buffer lacking MTX). The mature-sized proteins were then correctly localized in the intermembrane space (see Figure 5). Since the precursor arrested in translocation reaches the intermembrane space via the matrix (see below), these results indicate that export can occur in relatively close proximity to translocation contact sites. In order to have reached the intermembrane space, the translocation intermediates must have spanned three membranes, namely outer and inner membranes at contact sites and again the inner membrane near contact sites.

\section{Transport to the Intermembrane Space Requires hsp60}

Was hsp60 function required for the translocation-arrested fusion proteins to reach the intermembrane space? $\mathrm{pb}_{2}$ (331)-DHFR and $\mathrm{pb}_{2}$ (561)-DHFR were incubated with isolated mitochondria of mif 4 cells grown at the nonpermissive temperature. The temperature-sensitive yeast mutant mif4 has an altered gene coding for hsp60 (Cheng et al., 1989). Targeting of $\mathrm{pb}_{2}$ (331)-DHFR to the intermembrane space of mif 4 mitochondria, measured by processing to mature size, occurred with a 3-fold lower efficiency compared to wild-type mitochondria. With the longer fusion protein $\mathrm{pb}_{2}$ (561)-DHFR, processing to the mature species was almost completely blocked (Figure 3 , lanes 1-4). This was independent of the presence of MTX. The mutant mitochondria imported various mitochondrial matrix proteins with an efficiency close to that of wild-type mitochon-

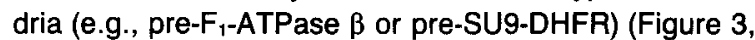
lanes 5-8).

Experiments were carried out to demonstrate a physical interaction between the $\mathrm{pb}_{2}$-DHFR fusion proteins and hsp60-14mer. The topology of mature-sized $b_{2}(331)$ DHFR arrested in contact sites in the presence of MTX was analyzed as a representative example (Figure 4). Upon removal of the MTX-stabilized DHFR moiety by protease treatment, the resulting cytochrome $b_{2}$ part remained in a protease-protected position within the organelles, whereas the DHFR part was released into the supernatant (Figure 4A). The protease-treated mitochondria contained a major fragment of about $\mathbf{2 8} \mathrm{kd}$ (in addition to a few minor fragments of slightly smaller size), which was precipitated by antibodies directed against cytochrome $b_{2}$ but not by anti-DHFR antibodies (Figure 4A, lanes 4 and 5). The size of the observed protein band was in good agreement with a fragment of 261 amino acids ( $27 \mathrm{kd}$ ) expected to remain from the 331 residues of pre-cytochrome $b_{2}$ after removal of the 80 residue presequence. Based on content of radiolabeled methionines, the main fragments were produced with a yield of more than $60 \%$ and thus must have originated from the mature-sized fusion protein arrested in translocation. To stabilize a possible interaction of the cytochrome $b_{2}$ fragments with $h s p 60$, the mitochondria were depleted of endogenous ATP by incubation with apyrase (Ostermann et al., 1989). Digitonin extracts were prepared and were separated by sizing chromatography on Sephacryl S300. About $40 \%-50 \%$ of the main fragment of 28 kd cofractionated with the $\sim 800 \mathrm{kd}$ hsp60 complex. The amount of hsp60-associated material was unchanged 
A

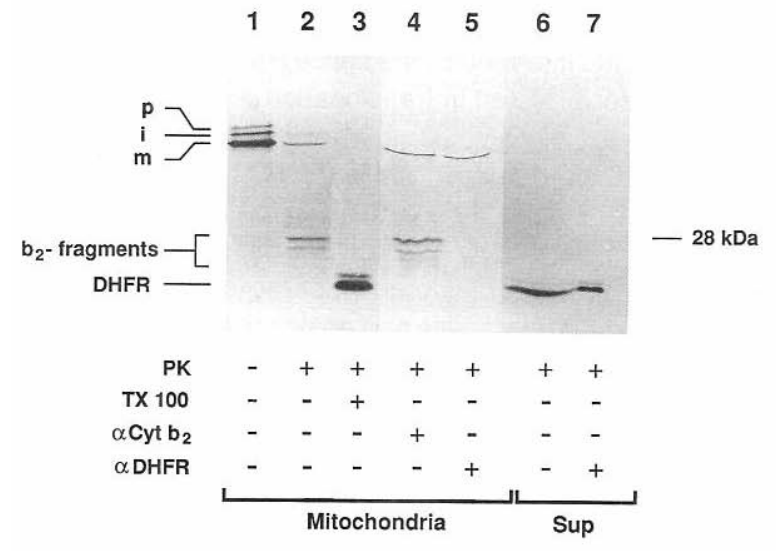

B
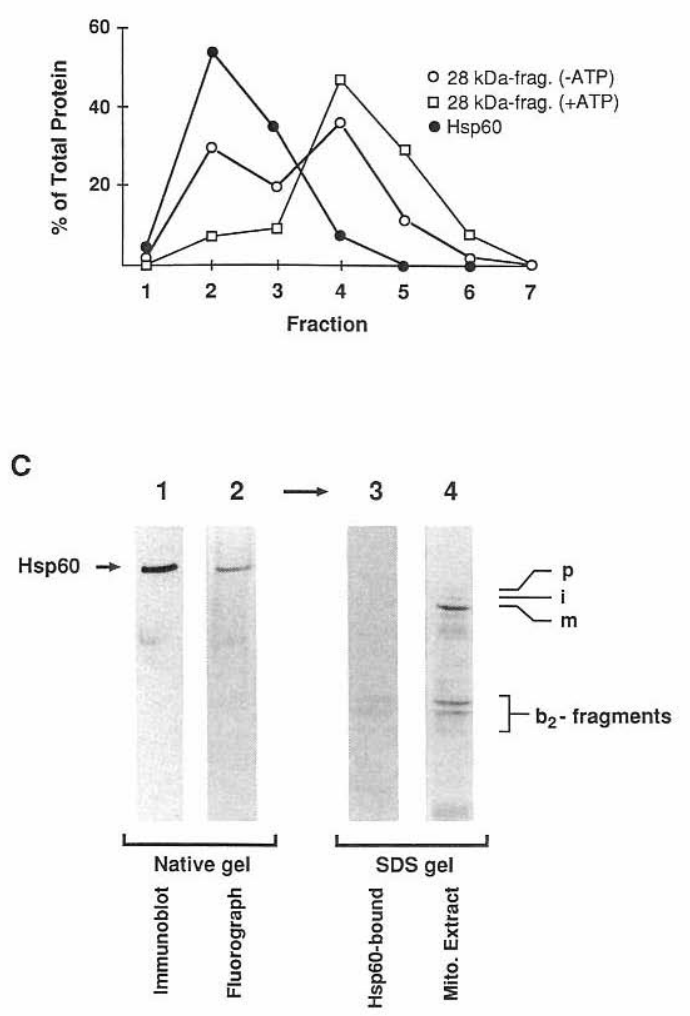

Figure 4. Association of Partially Translocated $b_{2}(331)$-DHFR with hsp 60

(A) Generation of cytochrome $b_{2}$-derived fragment. $\mathrm{pb}_{2}$ (331)-DHFR fusion protein was imported into mitochondria of wild type in the presence of MTX as in Figure 2. Mitochondria were reisolated from the import reaction by centrifugation. The mitochondrial pellet was resuspended at $0.5 \mathrm{mg} / \mathrm{ml}$ in SM buffer containing $1 \mathrm{mM} \mathrm{MgOAC,} 1 \mu \mathrm{M} \mathrm{MTX}$, and $1 \mu \mathrm{M}$ valinomycin and divided into five portions. Reactions 2-5 were treated with $15 \mu \mathrm{g} / \mathrm{ml}$ PK for $15 \mathrm{~min}$ at $0^{\circ} \mathrm{C}$ (+PK). In reaction 3 , $1 \%$ Triton X-100 was added prior to protease treatment. Reactions 1 and 2 and 4 and 5 were separated by centrifugation into mitochondrial pellets (lanes 1, 2, 4, and 5) and supernatants (lanes 6 and 7), while reaction 3 was TCA-precipitated (lane 3). Reactions 1-3 were directly analyzed by SDS-PAGE (lanes 1-3). The mitochondrial pellets of reactions 4 and 5 were solubilized in SDS-containing buffer and were diluted 20 -fold in Triton buffer ( $10 \mathrm{mM}$ Tris- $\mathrm{HCl}, 300 \mathrm{mM} \mathrm{NaCl}, 1 \%$ Triton X-100 [pH 7.5]), and immunoprecipitation was carried out using anti-cytochrome $b_{2}$ (lane 4) and anti-DHFR (lane 5) antisera and protein A-Sepharose (see Experimental Procedures). The supernatant frac- when the digitonin extracts were prepared in the presence of a high excess of $\alpha_{s 1}$-casein, which binds to hsp60 (not shown) (Martin et al., 1991). This excludes that binding to hsp60 occurred in the course of preparing the mitochondrial extracts. In contrast, most of the fragment extracted from ATP-containing mitochondria was not associated with hsp60 and fractionated at a low molecular weight on the sizing column (Figure 4B). This material probably had completed transiocation to the intermembrane space once the folded DHFR moiety was removed. The pooled column fractions 2 and 3 from an extract of apyrase-treated mitochondria were subjected to native polyacrylamide gel electrophoresis (PAGE) (Musgrove et al., 1987; Ostermann et al., 1989). The $28 \mathrm{kd}$ fragment, identified by subsequent SDS-electrophoresis of the hsp60-containing band, coelectrophoresed with the hsp60 complex on the native gel (Figure 4C).

These data demonstrate that the translocation-arrested precursor spanning three membranes reaches the intermembrane space via the matrix compartment where it interacts with hsp60. The chaperonin is apparently required for the sorting of the $\mathrm{pb}_{2}$ fusion proteins even if they engage in export before import into the matrix is complete.

tions of reactions 2 and 4 were TCA precipitated. The precipitate of reaction 2 was directly analyzed by SDS-PAGE (lane 6), while the precipitate of reaction 4 was subjected to immunoprecipitation as above using anti-DHFR antiserum. The fluorograph of an SDS-polyacrylamide gel is shown. The positions of precursor $(p)$, intermediate (i), and mature $(m) b_{2}(331)$-DHFR, as well as of cytochrome $b_{2}$-derived fragments and of protease-resistent DHFR are indicated.

(B) Fractionation by sizing chromatography. $\mathrm{pb}_{2}(331)$-DHFR was imported in the presence of MTX, and mitochondria were reisolated and suspended in SM buffer as above. A further incubation was carried out for $15 \mathrm{~min}$ at $25^{\circ} \mathrm{C}$ in the presence (reaction 1) or absence (reaction 2) of $20 \mu \mathrm{M}$ oligomycin and $40 \mathrm{U} / \mathrm{ml}$ apyrase (final concentrations, respectively). Both reactions were diluted 2-fold with BSA medium containing $1 \mu \mathrm{M} \mathrm{MTX}$, and protease treatment was performed as above. The mitochondria were pelleted, suspended in SEM buffer, and pelleted again. Soluble protein extracts were prepared by incubating the mitochondrial sediments for $2 \mathrm{~min}$ at $0^{\circ} \mathrm{C}$ in SEM buffer with 60 $\mathrm{mM} \mathrm{KCl}$ containing $0.35 \%$ digitonin $(5 \mathrm{mg} / \mathrm{ml}$ mitochondrial protein). After 5-fold dilution of the extracts with SEM buffer containing $60 \mathrm{mM}$ $\mathrm{KCl}$ and centrifugation for $10 \mathrm{~min}$ at $15,000 \times \mathrm{g}$, the resulting supernatants were fractionated on $2.5 \mathrm{ml}$ Sephacryl S-300 columns (equilibrated with $10 \mathrm{mM}$ MOPS, $60 \mathrm{mM} \mathrm{NaCl}, 0.02 \%$ Triton X-100, $0.2 \mathrm{mM}$ PMSF [pH 7.2]). The void volume was discarded, and $200 \mu$ l fractions were collected. Half of each fraction was TCA precipitated and analyzed by SDS-PAGE, immunoblotting with anti-hsp60 antiserum (see Experimental Procedures), and autoradiography. Amounts of hsp60 and of the main radiolabeled cytochrome $b_{2}$ fragment of $28 \mathrm{kd}$ were quantified by laser densitometry. Recoveries of protein loaded onto the columns was $>90 \%$. -ATP, reaction $1 ;$ ATP, reaction 2 . The fragments smaller than $28 \mathrm{kd}$ were generated in mitochondria with slightly damaged outer membrane allowing access of PK to the intermembrane space.

(C) Fractionation by nondenaturing electrophoresis. The second halves of column fractions 2 and 3 of reaction 1 (containing the peak concentrations of hsp60) were pooled. Aliquots of the pooled fraction were separated on a $4 \%-20 \%$ nondenaturing polyacrylamide gel (see Experimental Procedures). One part of the native gel was electrotransferred to nitrocellulose and analyzed by immunolabeling with anti-. hsp60 antiserum (lane 1) and autoradiography (lane 2). The hsp60. containing band was excised from the other part of the native gel, reelectrophoresed on a denaturing SDS-polyacrylamide gel and analyzed by fluorography (lane 3 ) in parallel with a mitochondrial extract containing the $b_{2}$-derived fragments prepared as above (lane 4). 


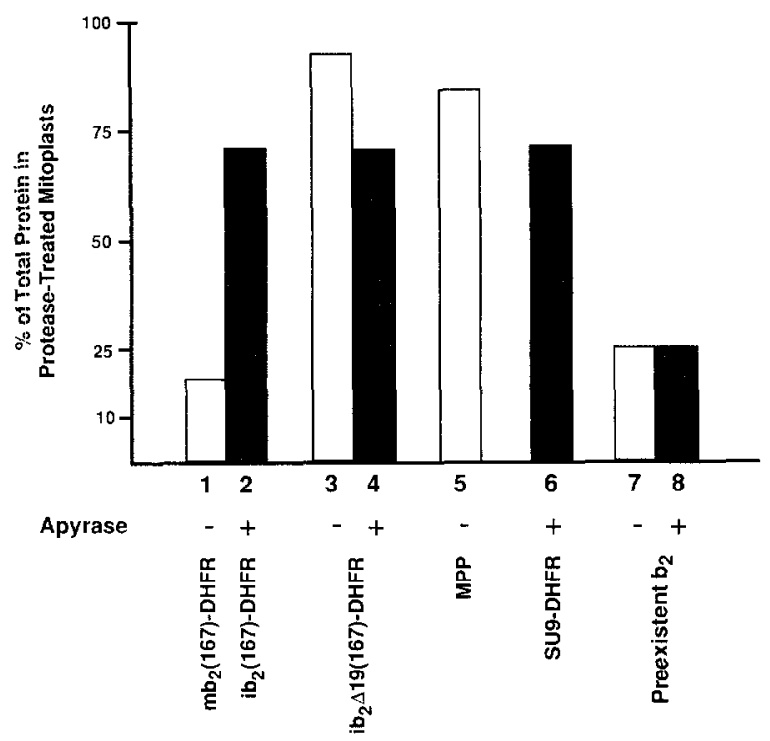

Figure 5. Subfractionation of Mitochondria Containing Imported bir-DHFR

Fiadiolabeled $\mathrm{pb}_{2}(167)-\mathrm{DHFR}$ and $\mathrm{pb}_{2} \Delta 19(167)$-DHFR were precipitated from reticulocyte lysates by ammonium sultate and were dissolved in $8 \mathrm{M}$ urea containing buffer (see Experimental Procedures). Frior to import, mitochondria were pretreated for $15 \mathrm{~min}$ at $25^{\circ} \mathrm{C}$ in the presence or absence of apyrase $(40 \mathrm{U} / \mathrm{ml}$ ) (+apyrase and -apyrase, respectively). The urea-denatured precursors were then diluted 30 -fold into import reactions containing the pretreated mitochondria in SM buffer and $80 \mathrm{mM} \mathrm{KCl}, 2.5 \mathrm{mM} \mathrm{MgOAc}, 2 \mathrm{mM} \mathrm{NADH}$. ATP was added to $2 \mathrm{mM}$ to the reactions lacking apyrase. After incubation at $25^{\circ} \mathrm{C}$, import was stopped by adding $1 \mu \mathrm{M}$ valinomycin and cooling on ice. Mitochondria were reisolated by centrifugation and were suspended in SEM buffer at a protein concentration of $20 \mathrm{mg} / \mathrm{ml}$. Half of each reaction was diluted 40-fold with either $10 \mathrm{mM}$ HEPES (pH 7.4) (for preparation of mitoplasts) or with SEM buffer. Following incubation for $15 \mathrm{~min}$ at $0^{\circ} \mathrm{C}$, these reactions were divided into three parts each. One part was treated with proteinease $K(15 \mu \mathrm{g} / \mathrm{ml}$, final concentration) while the second part remained on ice. The third part of the reaction was separated into pellet and supernatant for determination of the activity of preexistent cytochrome $b_{2}$ (columns 7 and 8 represent the activity of cytochrome $b_{2}$ associated with the mitoplast pellet), which was used as marker for the intermembrane space (see Experimental Procedures). The urea-denatured precursors of the matrix-localized processing peptidase imported in the presence of ATP (column 5) and of fusion protein pSU9-DHFR imported into apyrase-pretreated mitochondria (column 6) were analyzed as markers for the matrix compartment. Mitochondria and mitoplasts reisolated by centrifugation were analyzed by SDS-PAGE and fluorography. Amounts of protein remaining in protease-treated mitoplasts were quantified by densitometry and are expressed as percent of the amounts present in the protease-treated intact mitochondria. Activity of cytochrome $b_{2}$ in reisolated mitoplasts is expressed as percent of the activity present in intact mitochondria.

\section{Export Requires ATP-Dependent Release from hsp60}

The binding to hsp60 of proteins newly imported into the matrix can occur at very low levels of ATP. However, the release of the bound substrate protein requires ATP hydrolysis by hsp60 (Ostermann et al., 1989). If interaction with hsp60 represents an essential step of the export pathway, export should be dependent on ATP hydrolysis. This was tested using $\mathrm{pb}_{2}$ (167)-DHFR, since this short construct was able to reach the intermembrane space only after unfolding of its DHFR moiety, allowing translocation into the matrix (see Figure 2). Any apparent ATP dependence of the import into the matrix was circumvented by unfolding the precursor protein in $8 \mathrm{M}$ urea prior to import (Ostermann et al., 1989). Urea-denatured $\mathrm{pb}_{2}(167)$-DHFR was readily imported into ATP-depleted mitochondria obtained by apyrase treatment, but processing to the mature-sized form was strongly reduced and $\mathrm{ib}_{2}(167)$-DHFR accumulated. This intermediate was localized in the matrix, as demonstrated by subfractionation of the mitochondria (Figure 5, column 2). It remained protected against added protease in mitochondria whose outer membrane had been disrupted by osmotic swelling, as indicated by the loss of $75 \%$ of preexistent cytochrome $b_{2}$ from the intermembrane space (Figure 5, columns 7 and 8) (Daum et al., 1982.; Hartl et al., 1987). The $\mathrm{ib}_{2}$ (167)-DHFR was protected towards protease to the same extent as was, for instance, the mitochondrial processing peptidase subunit of the processing peptidase and the fusion protein Su9DHFR imported into the matrix. In contrast, the maturesized $b_{2}$ (167)-DHFR formed in the presence of ATP was located in the intermembrane space (Figure 5 , column 1).

To confirm the importance of the second part of the presequence of cytochrome $b_{2}$ as sorting signal to the intermembrane space, import of the fusion protein $\mathrm{pb}_{2} \Delta 19$ (167)-DHFR (see Figure 1) was analyzed. In this hybrid protein, the two main features of a potential bacterial-type export sequence (residues $47-80$ ) were disrupted by deleting its amino-terminal 3 positively charged residues plus the hydrophobic core (residues 55-65; based on hydropathy plots) of the carboxy-terminal segment. As expected, this fusion protein was found exclusively in the matrix (as the intermediate-sized form), independent of the presence or absence of ATP (Figure 5, columns 3 and 4).

Was the protein imported into apyrase-treated mitochondria associated with the hsp60 complex in an ATPdependent manner? Following import of $\mathrm{pb}_{2}$ (167)-DHFR, extracts were prepared from the ATP-depleted mitochondria and were analyzed on Sephacryl $\$ 300$ columns. Mostly ib $b_{2}$ (167)-DHFR was detected, which cofractionated with hsp60 (Figure 6A). A small amount of mature-sized $b_{2}$ (167)-DHFR formed in spite of ATP depletion. Only part of it fractionated with the molecular weight of the monomeric fusion protein. The physical interaction of $\mathrm{ib}_{2}(167)$. DHFR with hsp60 was demonstrated by coelectrophoresis of the radiolabeled protein with the hsp 60 complex on nondenaturing polyacrylamide gels. When the mitochondria were subjected to a $15 \mathrm{~min}$ chase period in the presence of ATP (Figure 6B), about $50 \%$ of the intermediate-sized protein became processed to the mature form. This $\mathrm{mb}_{2}$ (167)-DHFR was no longer associated with hsp60. In conclusion, the export of proteins from the matrix to the intermembrane space involves at least one ATP-dependent step that is related to the function of hsp60.

\section{Presence of the Export Signal Results} in Prolonged Interaction with hsp60

We analyzed the kinetics of the interaction of intermediatesized $b_{2}$-DHFR with $h s p 60$ in more detail (Figure 7). Ureadenatured $\mathrm{pb}_{2}$ (167)-DHFR (which is completely imported 


\section{A +Apyrase}

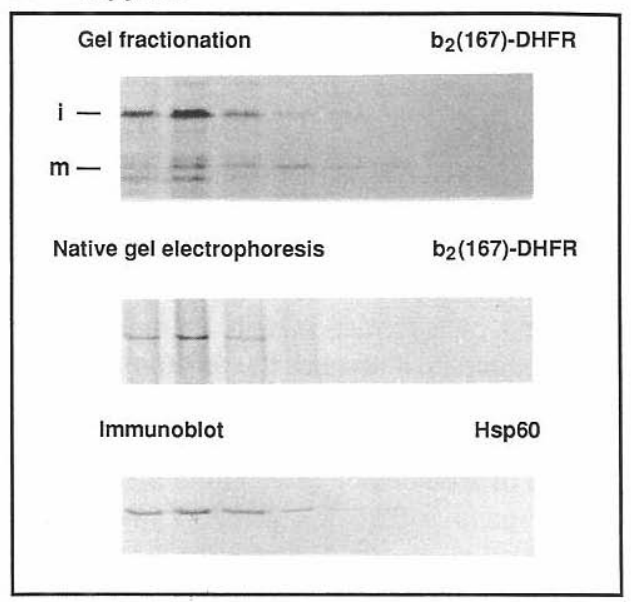

B + ATP

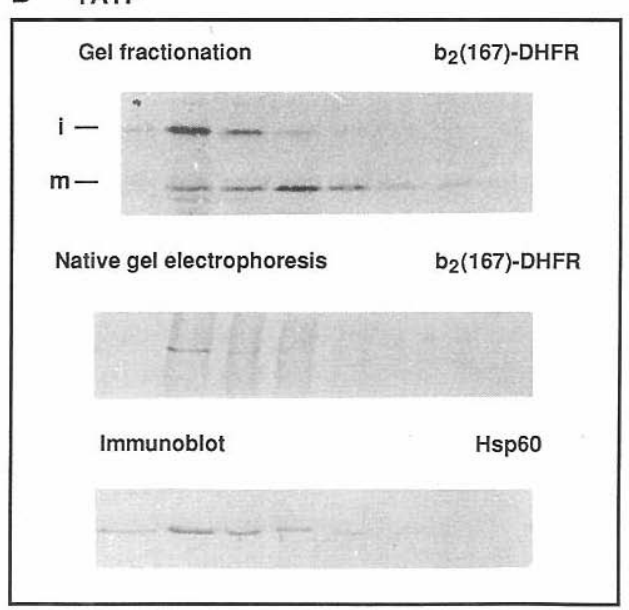

Fraction $\begin{array}{lllllllll}1 & 2 & 3 & 4 & 5 & 6 & 7 & 8\end{array}$

Figure 6. Accumulation of hsp60-Associated $b_{2}$ (167)-DHFR Urea-denatured $\mathrm{pb}_{2}$ (167)-DHFR was imported into apyrase-pretreated mitochondria as in Figure 5. After protease treatment, mitochondria were reisolated by centrifugation and suspended in BSA medium containing 0.3 mM PMSF. The mitochondrial suspension was divided (A and $B$ ). Mg-ATP (2 mM final concentration) was added to one half (B). After incubation for $15 \mathrm{~min}$ at $25^{\circ} \mathrm{C}$, mitochondria were isolated from both reactions, digitonin extracts were prepared and were fractionated on Sephacryl S300 columns as in Figure 4. Aliquots $(30 \mu l)$ of each fraction were separated on a nondenaturing polyacrylamide gel. The remaining part of each fraction was TCA-precipitated and was analyzed by SDS-PAGE and fluorography. The native gels were immunoblotted using anti-hsp60 antiserum.

into the matrix prior to export) was incubated with mitochondria in the presence of ATP. Translocation of the precursor was complete within 3-4 min. Aliquots of mitochondria were withdrawn within a 5-40 min incubation period. After 5 min of incubation, mostly $\mathrm{ib}_{2}$ (167)-DHFR was detected within mitochondria that was associated with hsp60. This $i b_{2}$-DHFR was slowly processed to the mature-sized form that was no longer associated with hsp60; it became localized in the intermembrane space (data not shown; see also Figure 5). Release from hsp60 was apparently coupled to export, with a half-time of 10

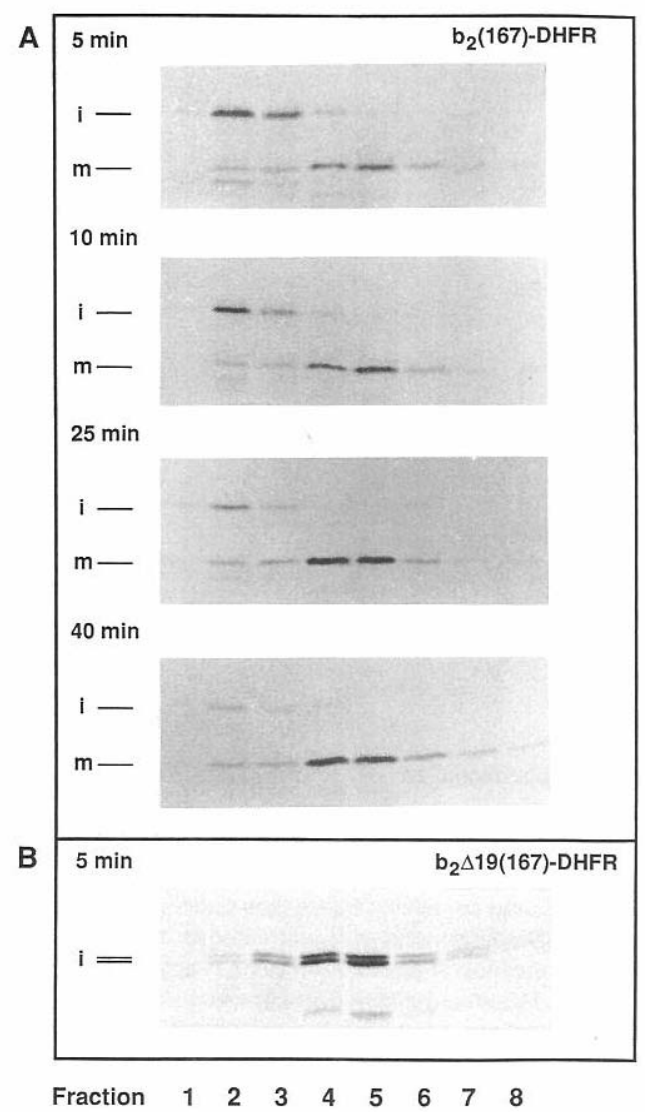

Figure 7. Transient Association of $b_{2}(167)$-DHFR with hsp60 During Import

Urea-denatured $\mathrm{pb}_{2}$ (167)-DHFR was imported into isolated mitochondria in the presence of $2 \mathrm{mM} \mathrm{NADH}$ and $2 \mathrm{mM}$ ATP. Import was complete after $\sim 3 \mathrm{~min}$ at $25^{\circ} \mathrm{C}$. At the times indicated, aliquots corresponding to $150 \mu \mathrm{g}$ mitochondrial protein were withdrawn and were cooled to $0^{\circ} \mathrm{C}$. Incompletely translocated protein was removed by treatment with PK. Soluble mitochondrial proteins were extracted by digitonin and were fractionated by gel chromatography as in Figure 4 and Figure 5 . Fractions eluted from the columns were analyzed by SDS-PAGE and fluorography. As a control, import of urea-denatured $p b_{2} \Delta 19(167)$ DHFR was analyzed after incubation for $5 \mathrm{~min}$ at $25^{\circ} \mathrm{C}$

$15 \mathrm{~min}$ and with nearly full efficiency (Figure 7). This was considerably slower than previously observed for a nonexported fusion protein between the presequence of Fo-subunit 9 and DHFR, which folds in the matrix with a half-time of $\sim 3$ min mediated by hsp60 (Ostermann et al., 1989). Notably, over $90 \%$ of total ib $b_{2}$-DHFR present in mitochondria at any time point of the experiment were in a soluble complex with hsp60, indicating that export occurred from a soluble pool of import intermediate.

It seemed possible that the export signal in the presequence of cytochrome $b_{2}$ containing a hydrophobic segment (residues 55-71) plays a critical role in maintaining the prolonged interaction with hsp60. To test this, the fusion protein $\mathrm{pb}_{2} \Delta 19(167)$-DHFR, which lacks the functional export sequence, was used (see Figure 1). Upon denaturation with urea, this protein was imported into the mitochondrial matrix with the same kinetics as $\mathrm{pb}_{2}(167)$ DHFR. (Cleavage of the deletion construct in the matrix 


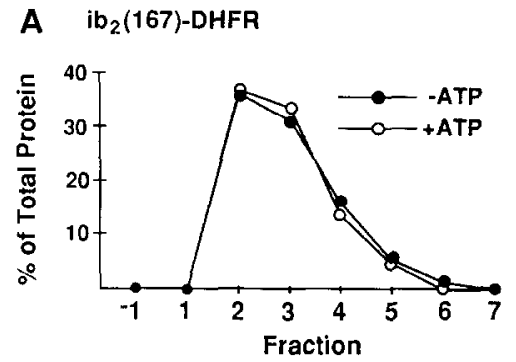

B ib 2 $19(167)-D H F R$
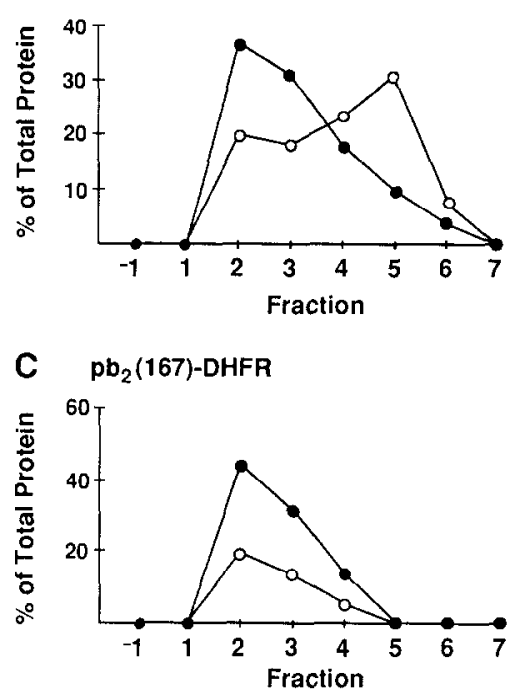

D $\quad \mathrm{pb}_{2} \Delta 19(167)-$ DHFR

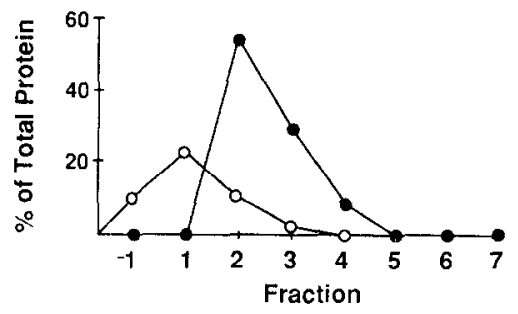

Figure 8. Effect of Mg-ATP on hsp60-Associated $b_{2}$-DHFR

(A) and $(B) A$ mixture of urea-denatured $\mathrm{pb}_{2}(167)$-DHFR $(A)$ and $\mathrm{pb}_{2} \Delta 19(167)$-DHFR (B) was imported in the absence of ATP into apyrase-pretreated mitochondria. Protease treatment was performed, and a digitonin extract was prepared as in Figure 4. The extract was adjusted to $100 \mathrm{mM} \mathrm{KCl}$ and was divided into halves. (C) and (D) 10 $\mu \mathrm{g}$ each of purified $\mathrm{pb}_{2}(167)$-DHFR (C) and $\mathrm{pb}_{2} \Delta 19(167)$-DHFR (D), respectively, were unfolded in guanidinium buffer ( $6 \mathrm{M}$ guanidinium$\mathrm{HCl}, 20 \mathrm{mM}$ Tris-HCl [pH 7.4], $50 \mathrm{mM}$ DTT) and were rapidly diluted 70-fold into a final volume of $160 \mu \mathrm{l}$ association buffer (15 $\mathrm{mM}$ MOPS [pH 7.2], $50 \mathrm{mM} \mathrm{KCl}, 1.5 \mathrm{mM}$ DTT) containing $330 \mu \mathrm{g}$ purified groEL (1.5-fold molar excess over the fusion proteins) and $28 \mu \mathrm{g}$ purified groES (equimolar to groEL). After $3 \mathrm{~min}$ incubation at $25^{\circ} \mathrm{C}$, aggregated fusion proteins were removed by centrifugation (15 min, 20,000 $\times \mathrm{g}$ ), and the supernantants were used for further incubation. Chase incubation of (A-D): one half of each reaction was incubated for $15 \mathrm{~min}$ at $25^{\circ} \mathrm{C}$ in the presence of ATP (+ATP) and the other half in the absence of $5 \mathrm{mM} \mathrm{Mg-ATP}$ (-ATP). Then all reactions were cooled and fractionated by gel chromatography on Sephacryl $S 300$ columns. Fractions were separated by SDS-PAGE, electrotransferred to nitrocellulose and analyzed by autoradiography and immunolabeling using antihsp60 antiserum ( $A$ and $B$ ). Fractionation of the fusion proteins and of groEL was monitored by immunolabeling with anti-DHFR and anti- yields two processed species of similar size.) However, the kinetics of its interaction with hsp60 were strikingly different. Already, after 5 min of incubation, most of the deletion construct was released from hsp60 (Figure 7, lower panel) and was located in the matrix (see Figure 5).

In addition to its function in targeting to the intermembrane space, the signal sequence for export of precytochrome $b_{2}$ appears to regulate directly or indirectly the interaction with hsp60. We tested whether ATP hydrolysis by hsp60 alone was sufficient for releasing the bound $\mathrm{ib}_{2}$ (167)-DHFR in the absence of a functional inner membrane. Upon incubation for up to $15 \mathrm{~min}$ in the presence of ATP, the $\mathrm{ib}_{2}$ (167)-DHFR contained in digitonin extracts of ATP-depleted mitochondria remained firmly bound to hsp60, as revealed by sizing chromatography (Figure 8A). In contrast, the hybrid protein lacking most of the hydrophobic segment in the presequence was efficiently released from hsp60 under these conditions (Figure 8B).

\section{Purified Chaperonin Acts Differentially on Exported and Matrix-Localized Proteins}

hsp60 could have the intrinsic ability to distinguish between proteins with different final localizations within mitochondria. Alternatively, a further as yet unidentified component, perhaps interacting with the export sequence of cytochrome $b_{2}$, might be required to guarantee the prolonged binding of the intermembrane space protein to hsp60. To address this question, we attempted to reproduce the interaction between the $b_{2}$-DHFR fusion proteins and the chaperonin in vitro using purified components. These experiments were performed with the E. coli chaperonin groEL rather than with hsp60, based on the following considerations: GroEL is highly homologous to mitochondrial hsp60 with respect to structure and function (Hemmingsen et al., 1988; Reading et al., 1989). GroEL is known to have a chaperone function in protein export to the periplasmic space (Bochkareva et al., 1988; Kusakawa et al., 1989). More importantly, both groEL and the cooperating heat shock protein groES are easiliy purified from an overproducing strain of E. coli (Fayet et al., 1986), while the mitochondrial groES cooperating with hsp60 is rather difficult to isolate in large quantities (Lubben et al., 1990). The fusion proteins $\mathrm{pb}_{2}(167)-\mathrm{DHFR}$ and $\mathrm{pb}_{2} \Delta 19(167)$ DHFR were expressed in $\mathrm{E}$. coli as inclusion bodies, purified to homogeneity, and dissolved in $6 \mathrm{M}$ guanidinium- $\mathrm{HCl}$. Both polypeptides aggregated when diluted from denaturant into buffer (not shown). In contrast, when added to a reaction containing a 1.5-fold molar excess of groEL, they formed stable complexes with groEL that could be isolated by sizing chromatography (Figures $8 \mathrm{C}$ and $8 \mathrm{D}$ ). The groEL-bound proteins were incubated for $15 \mathrm{~min}$ at $25^{\circ} \mathrm{C}$ in the presence of $\mathrm{Mg}-\mathrm{ATP}$ and groES (equimolar to groEL), which is known to regulate the ATPase activity of groEL (Chandrasekhar et al., 1986;

groEL antisera (C and D). Proteins were quantified by densitometry. Amounts are given in percent of protein recovered from the sizing columns. In the absence of ATP, the fusion proteins exactly cofractionated with hsp60 and groEL, respectively. 

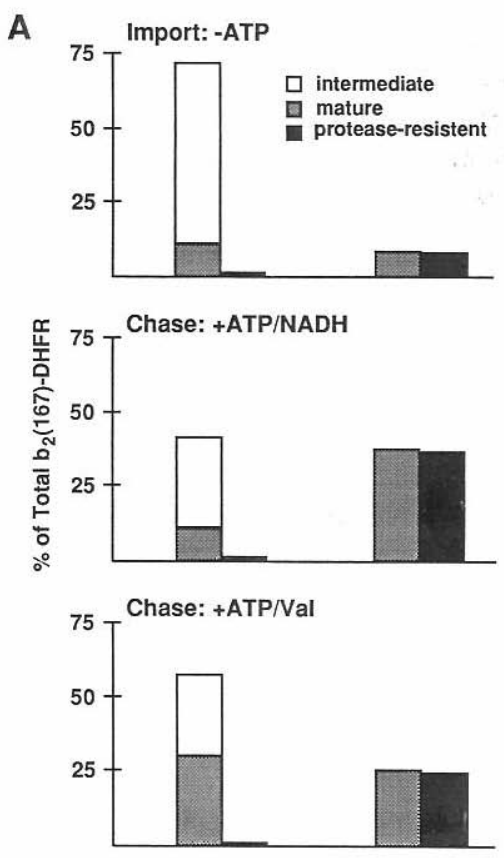

B

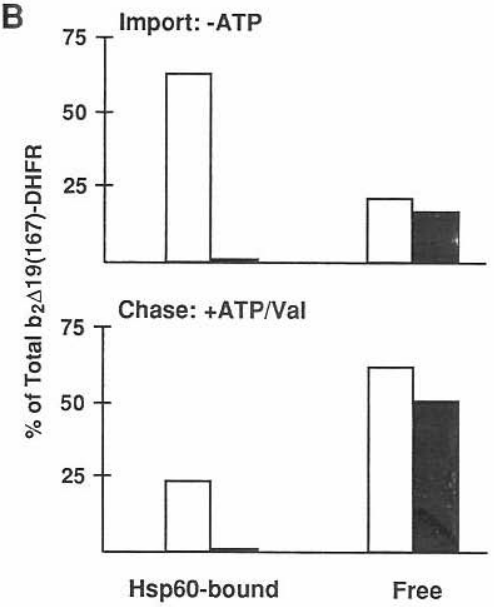

Figure 9. Intrinsic Protease Resistance of hsp60-Associated $b_{2}$-DHFR Urea-denatured $\mathrm{pb}_{2}$ (167)-DHFR (A) and $\mathrm{pb}_{2} \Delta 19(167)-D H F R(B)$ were imported into apyrase-treated mitochondrla as in Figure 5. Mitochondria were isolated from the import reactions by centrifugation and were suspended in BSA medium. One part of each reaction remained on ice to maintain the apyrase block (-ATP). A second part (for [A] only) was supplemented with $2.5 \mathrm{mM}$ MgOAc, $2 \mathrm{mM}$ ATP, and $2 \mathrm{mM} \mathrm{NADH}$ (+ATP/NADH) and a third part with $2.5 \mathrm{mM} \mathrm{MgOAc}, 2 \mathrm{mM}$ ATP, and $1 \mu \mathrm{M}$ valinomycin (+ATPNal). These reactions were incubated for 15 $\mathrm{min}$ at $25^{\circ} \mathrm{C}$ (Chase). Mitochondria were isolated from all reactions, digitonin extracts were prepared and separated by gel chromatography (see Figure 4). Each fraction eluted from the column was divided and one half was treated with PK ( $25 \mu \mathrm{g} / \mathrm{ml}$ final concentration) for 10 min at $0^{\circ} \mathrm{C}$. After addition of PMSF, TCA precipitates were analyzed by SDS-PAGE, and electrotransfer to nitrocellulose followed by immunolabeling of hsp60 and autoradiography. Radiolabeled proteins and hsp60 were quantified by densitometry. hsp60-bound protein is defined as the amount of imported $b_{2}$ (167)-DHFR or $b_{2} \Delta 19(167)$-DHFR in column fractions $1-3$ containing $\sim 80 \%$ of total hsp60 loaded onto the column. Free imported protein is the amount of $b_{2}(167)$-DHFR or $b_{2} \Delta 19(167)$-DHFR in column fractions 4-7 containing only a small amount of hsp60 (compare Figure 4B). For $b_{2}$ (167)-DHFR, amounts of intermediate and mature protein are given. $\left(b_{2} \Delta 19(167)\right.$-DHFR is not processed to the mature form.) Amounts are given in percent of total protein recovered from the column.
Viitanen et al., 1990; Martin et al., 1991). Under these conditions, only about $50 \%$ of $b_{2}(167)$-DHFR containing the targeting sequence for export was released from the chaperonin (Figure $8 \mathrm{C}$ ), as confirmed by analyzing the amount of $b_{2}$-DHFR coelectrophoresing with groEL on nondenaturing polyacrylamide gels (not shown). Strikingly, the same result was obtained when the chromatographic separation was performed in the presence of $\mathrm{Mg}-\mathrm{ATP}$ at $25^{\circ} \mathrm{C}$ instead of $4^{\circ} \mathrm{C}$. This suggests that the chaperonin-bound state is preserved for prolonged periods because of slow release from groEL rather than repeated ATP-dependent release and rebinding. The released $b_{2}(167)$-DHFR was unable to refold and formed aggregates that were not recovered from the Sephacryl columns but could be eluted with $8 \mathrm{M}$ urea. In contrast, essentially all of the $\mathrm{pb}_{2} \Delta 19(167)$-DHFR was displaced from groEL upon incubation in the presence of $\mathrm{Mg}-\mathrm{ATP}$ (Figure 8D). Half of the released protein was recovered as aggregates. The tendency to form aggregates was not as great at lower concentrations of the precursor or with the intermediate-sized $b_{2} \Delta 19(167)$-DHFR produced by incubation with purified matrix-processing enzyme (Hawlitschek et al., 1988). This can explain the ability of $\mathrm{ib}_{2} \Delta 19(167)-D H F R$ to form the folded monomer within mitochondria at low concentrations of Imported protein (see above). However, aggregates of $\mathrm{ib}_{2} \Delta 19(167)$-DHFR were also produced in the mitochondrial matrix when microgram quantities of the purified precursor were imported (not shown). We noted that in the absence of groES, the ATP-dependent release of both fusion proteins from groEL was delayed to an extent comparable with that observed in mitochondrial extracts. Most likely, the stable interaction of groES with the chaperonin, which is known to require the presence of ATP or ADP (Viitanen et al., 1990), was lost in the ATP-depleted mitochondrial extracts.

In summary, these data indicate that hsp60 and its homologs are able to distinguish proteins destined for export from those residing in the mitochondrial matrix. hsp60 appears to be sufficient to carry out this function without the requirement for further components interacting with the protein substrate.

\section{hsp60 Prevents Premature Folding Prior to Export} What are the effects of complex formation with hsp60 on the conformation of intermediate-sized $b_{2}$-DHFR destined for export? Urea-denatured $\mathrm{pb}_{2}$ (167)-DHFR and $\mathrm{pb}_{2} \Delta \mathbf{1 9}$ (167)-DHFR were imported in the absence of ATP. As a measure for protein conformation, we tested the intrinsic resistance of $b_{2}$-DHFR to proteinase $K(P K)$ in mitochondrial extracts. As pointed out, the folded DHFR moiety is very protease resistant (see Figure 4). Both hsp60associated proteins were highly sensitive towards added protease indicating that they were in a loosely folded, nonnative conformation (Figure 9). Protease-resistant fragments were not detected. Upon incubation of the mitochondria for a $15 \mathrm{~min}$ chase period in the presence of ATP and NADH (to maintain a high potential across the inner membrane), about half of the ib. (167)-DHFR was released from hsp60 and was processed to the mature form (Figure 9A). The DHFR moiety of this free $\mathrm{mb}_{2}(167)$-DHFR was 
folded to the native, protease-resistant conformation. It was localized in the intermembrane space (data not shown). Interestingly, when during the chase period in the presence of ATP the membrane potential was dissipated by the potassium ionophore valinomycin, the complete release of $\mathrm{ib}_{2}$ (167)-DHFR from hsp60 was retarded (Figure 9A). A considerable amount of mature-sized $b_{2}(167)$ DHFR accumulated that was still associated with hsp60 but was highly sensitive toward protease. Apparently, this $\mathrm{mb}_{2}$-DHFR was caught in the process of translocation back across the inner membrane. Its amino-terminal presequence had reached the intermembrane space and was cleaved, while the mature part of the protein including the DHFR moiety was still associated with hsp60 awaiting translocation. In contrast to the observations with $b_{2}(167)-$ DHFR, the deletion construct $b_{2} \Delta 19(167)$-DHFR was efficiently released from hsp60 and folded even in the presence of valinomycin (Figure $9 \mathrm{~B}$ ). This may suggest that the membrane potential of the inner membrane constitutes part of the driving force for protein export.

We conclude that hsp60 has a dual function: mediating the folding of proteins remaining in the matrix, and efficiently preventing folding and aggregation in the case of proteins that have to undergo further membrane translocation to the intermembrane space. The presence or absence of the amino-terminal export signal determines which of these alternative functions of hsp60 becomes effective. In order to be successfully released, we assume the bound protein must be handed over from hsp60 to a component(s) of the export apparatus in the inner membrane. Release from hsp60 and subsequent membrane translocation appear to be tightly coupled to avoid premature folding of the protein in the matrix.

\section{Discussion}

The chaperonin hsp60 plays a critical role in the routing of proteins to the mitochondrial intermembrane space. The following sequence of events can now be described for the sorting pathway of cytochrome $b_{2}$ (Figure 10). First, mitochondrial hsp70 binds the extended amino-terminal part of the precursor reaching into the matrix at contact sites (Kang et al., 1990; Scherer et al., 1990; Ostermann et al., 1990). This interaction is required for efficient translocation. Second, the precursor is then transferred to hsp60. Association with the chaperonin in a manner dependent on the hydrophobic export sequence maintains the protein in an unfolded state competent for subsequent export. Third, recognition of the export sequence by an as yet unknown component of the export apparatus in the inner membrane triggers the ATP-dependent release of the protein from hsp60. Fourth, hsp60-dependent export can occur either concomitantly with import at contact sites or following complete translocation of the precursor into the matrix.

hsp60 is known to mediate the ATP-dependent folding and oligomeric assembly of proteins residing in the mitochondrial matrix (Cheng et al., 1989; Ostermann et al., 1989). The structural basis of substrate recognition by hsp60 is not yet understood, but it was recently proposed

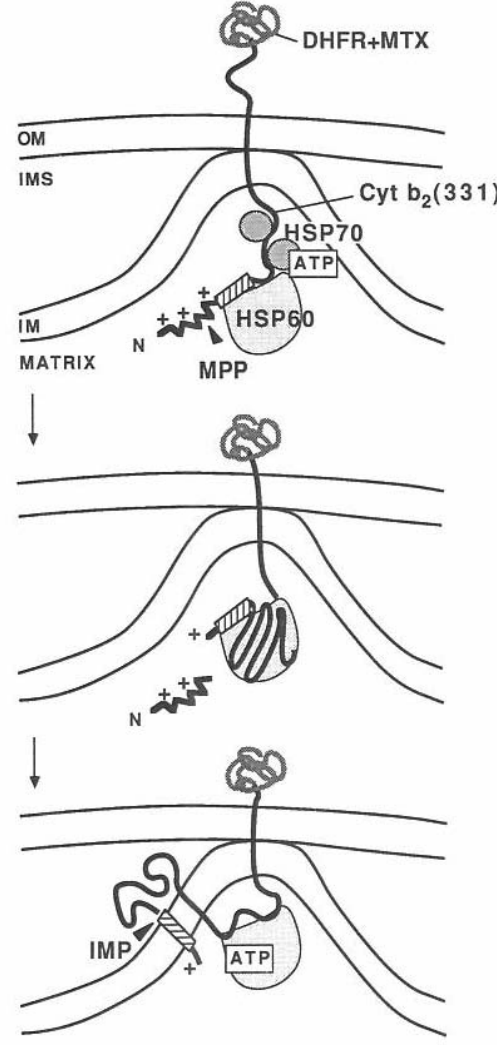

Figure 10. Working Model for the Targeting of Cytochrome $b_{2}$ to the Intermembrane Space

Partial translocation across outer and inner membranes at contact sites followed by export to the intermembrane space near contact sites. The fusion protein $b_{2}(331)$-DHFR is shown, which is blocked in translocation by the MTX-stabilized DHFR moiety. In the absence of MTX, translocation into the matrix occurs more rapidly than export, and the complete protein is bound to hsp60 before making contact with the export apparatus in the inner membrane (see Discussion for details). OM, outer membrane; IMS, intermembrane space; IM, inner membrane; MPP, mitochondrial processing peptidase; IMP, inner membrane protease. MTX, methotrexate; hatched box, hydrophobic segment in the export sequence. The closest proximity of import and export sites in the inner membrane was estimated as follows: $\mathbf{5 0}$ amino acid residues amino terminally to the MTX-stabilized DHFR are sufficient to span the two membranes at contact sites (Rassow et al., 1990). The presequence of cytochrome $b_{2}$ is 80 residues long (Guiard, 1985). According to the loop model of protein secretion, the amino-terminal part of the mature sequence (10-20 residues) of cytochrome $b_{2}$ would have to span the inner membrane during export. It follows that in case of $b_{2}(220)$-DHFR, $\sim 80$ residues were sufficient to bridge the distance beween import and export sites. In its longest extension, such a sequence translates into $\sim 29 \mathrm{~nm}$ (Pauling and Corey, 1951).

that the hsp60 homolog groEL may recognize amphiphilic $\alpha$-helices of 15-20 residues length exposed by loosely folded polypeptides (Landry and Gierasch, 1991). In the absence of ATP, groEL stabilizes proteins in an intermediate folded conformation lacking stable tertiary structure (Martin et al., 1991). Folding to the native state occurs upon ATP hydrolysis probably by a process of step-wise or partial release from the chaperonin scaffold, which is regulated by groES or its mitochondrial homolog (Martin et al., 1991; Lubben et al., 1990).

We have reported a novel function of hsp60, namely 
antifolding activity exerted on proteins passing through the matrix en route to the intermembrane space. How does hsp60 fulfill this apparently contradictory role? Our results show that the signal sequence for export is of critical importance in "switching" the function of hsp60 from mediating to preventing folding. The hydrophobic signal sequence of cytochrome $b_{2}$, a predicted $\alpha$-helix, may itself be a strong binding element for hsp60, thus preventing adjacent segments of the protein from participating in folding. If released upon ATP hydrolysis, the prepeptide would not become buried due to folding but remain available for immediate rebinding. Consequently, folding of the complete polypeptide would either be entirely prevented or at least strongly retarded. In principle, the export sequence could also act indirectly by interfering with the folding of the mature part of the precursor, as has been suggested for other secretory proteins (Liu et al., 1989; Randall and Hardy, 1989; Laminet and Plückthun, 1989). It seems unlikely, however, that in the reaction with hsp60 described in this study the signal sequence would prevent folding entirely by an indirect mechanism. The fusion protein lacking the export signal is normally released from hsp60 (or its homolog groEL) even under conditions where the protein is unable to fold efficiently and does aggregate. Thus, the intrinsic property of the protein to fold slowly would not be sufficient for hsp60 to prevent its (mis)folding. On the other hand, the fusion protein with the intact export sequence is able to fold to a soluble protein containing native DHFR when synthesized in a reticulocyte lysate (see also Rassow et al., 1989). Apparently, the export sequence per se does not prevent folding, but does so in the context with hsp60. The underlying mechanism of this function is unclear, but it is conceivable that different types of signals exist that direct the various functions of hsp60 in folding, antifolding, and assembly. Possibly, the export sequence has an inhibitory effect on the ATP hydrolytic release activity of hsp60. Consistent with this idea, the specific function of hsp60 in preventing folding is maintained as long as the export sequence is present and remains accessible to hsp60. In this model, only the removal of the signal by binding to an as yet unidentified component of the export apparatus would allow the protein to free itself from hsp60 for translocation. Folding would remain blocked under translocation conditions by a signal-independent mechanism since then only part of the protein is available for folding at the matrix side of the membrane.

The requirement for prevention of folding prior to export results from the fact that the import and export events are not very tightly coupled. The kinetics of export are slower than those of import (Hartl et al., 1987). The uptake of proteins into mitochondria in vivo is a very rapid process (Hallermayer et al., 1977), occurring with kinetics comparable to those observed with import of artificially unfolded precursor proteins in vitro. Under physiological conditions, proteins destined for export may not get immediate access to an export site in the inner membrane during import. When rapidly translocated in vitro, these proteins accumulate in a soluble pool as unfolded hsp60-bound intermediates awaiting export for several minutes. Evidence obtained with the hsp60-deficient mif4 strain of yeast suggests that this may also be the case in vivo (Cheng et al., 1989). hsp60 thus forms a reservoir for imported proteins that have to undergo further transport, based on its capability to distinguish these proteins from those remaining in the matrix. Export can occur concomitantly with import, but only when sufficiently long polypeptide chains are allowed the time (by artificially blocking translocation) to recruit export sites before import is complete. Also in these cases, prevention of incorrect folding by hsp60 is required prior to export, suggesting that import into the matrix and contact of the hydrophobic signal sequence with the export machinery do not occur in rapid succession.

hsp60 appears to be a major chaperone for protein export in mitochondria, in contrast with the related process of bacterial secretion in which SecB seems to be more important (Liu et al., 1989; Randall and Hardy, 1989; Hartl et al., 1990). A mitochondrial homolog of SecB has not yet been identified. However, the participation of additional components in export to the intermembrane space is possible. A natural candidate for such a function would be the mitochondrial hsp70, Ssc1p, since its E. coli homolog, DnaK, facilitates protein export at least in certain cases (Philips and Silhavy, 1990). The mitochondrial hsp70 interacts with the newly imported polypeptides prior to hsp60 (Kang et al., 1990; Scherer et al., 1990; Ostermann et al., 1990). It seems possible that for certain proteins the interaction with hsp70 may be sufficient to prevent incorrect folding prior to export.

Our findings assign a new function to translocation contact sites between outer and inner mitochondrial membranes. In addition to the apparatus for import (Schleyer and Neupert, 1985; Schwaiger et al., 1987; Vestweber and Schatz, 1988), these membrane regions can be in close proximity to at least some of the sites required for the export of proteins. The distance between import and export sites can be as little as $30 \mathrm{~nm}$ (see Figure 10 legend). The majority of protein export may occur at inner membrane areas outside of contact sites, however. Assuming that import and export can proceed cotranslocationally, with certain precursor proteins and under conditions of slow import in vitro, this may explain why intermembrane space proteins such as cytochrome $b_{2}$ and cytochrome $c_{1}$ are not readily detectable as completely imported intermediates in the matrix (van Loon et al., 1986, 1987; van Loon and Schatz, 1987). It needs to be pointed out, though, that export is not mechanistically coupled to import across contact sites, just as cotranslational translocation into the endoplasmic reticulum is mechanistically independent of elongation. Clearly, mitochondrial protein export has preserved the characteristic features of bacterial secretion.

Our observations thus unify mitochondrial protein export with related translocation systems such as bacterial protein export, transport into the endoplasmic reticulum, and perhaps the translocation of proteins into the thylakoid lumen of chloroplasts. The mechanisms of protein import into mitochondria and chloroplasts, on the other hand, are likely to have developed later in evolution, following their respective endosymbiotic events. 


\section{Experimental Procedures}

\section{Fusion Proteins}

A series of hybrid genes was constructed encoding the amino-terminal portions of the precursor of the yeast cytochrome $b_{2}$ (1-167 up to 1-561 residues) fused to the entire cytosolic mouse DHFR. An EcoRI site was introduced at position -23 in front of the cytochrome $b_{2}$ open reading frame (Guiard, 1985), and the resulting $2.3 \mathrm{~kb}$ EcoRI-HindlII fragment was cloned in the plasmid PGEM (authentic cytochrome $b_{2}$ ). From this construction, the DNA fragments BamHI-HindllI and KpnlHindIII were deleted and replaced by the BamHI-HindIII fragment containing the entire DHFR gene. DNA adaptors were used to restore the frame between the fused genes inserting extra amino acids, 8 residues (PGIHRSGI) in $\mathrm{pb}_{2}$ (331) and five residues (RGSGI) in pb $\mathrm{pb}_{2}(561)$. EcoRIBgill fragments encoding the amino-terminal $1-220$ and $1-260$ residues of pre-cytochrome $b_{2}$ were engineered using polymerase chain reaction technology. Polymerase chain reaction amplifications were performed with Replinase Thermostabile DNA Polymerase (NEN). Primers used for amplification were CGM1332 5'-GCCAAGATCTGCTIGTITAGTCAAAG-3', CGM1329 5'-GCCAAGATCTGAAATGTCTACTTTGCG-3' and CGM1241 5'-CCGAATTCCATGGTAAAATACAA$A C C-3$ ', which flanks the amino terminus of the CYB2 gene. The resulting fragments were used to replace the EcoRl-Bglil fragment of $\mathrm{pb}_{2}(561)$, yielding the constructions $\mathrm{pb}_{2}(220)-\mathrm{DHFR}$ and $\mathrm{pb}_{2}(260)$ DHFR. In each case, 8 extra amino acids (DLSRGSGI) were introduced between the fused genes. To generate $\mathrm{pb}_{2} \Delta 19(167)$-DHFR, a DNA segment coding for residues 47-65 of the presequence of cytochrome $b_{2}$ was removed from the plasmid $\mathrm{pb}_{2}(167)$-DHFR. For this purpose, a Xball site was introduced by in vitro mutagenesis at position +136 downstream of the ATG. The 520 bp EcoRl-BamHI fragment of $\mathrm{pb}_{2}(167)$ carrying the coding region for the first 167 amino acids of cytochrome $b_{2}$ was subcloned into $M 13 m p 19$. One oligonucleotide was prepared (CGM25 5'-GAACAAGACTCTAGAAAACGCAC-3') and used to mutagenize the mp 19 clone. The change was confirmed by sequencing. Double stranded DNA was prepared, and the mutated EcoRIBamHI fragment was substituted for the wild-type fragment in $\mathrm{pb}_{2}(167)$ to give the plasmid $\mathrm{pb}_{2}(167) \times 1$. The plasmid $\mathrm{pb}_{2}(167) \times 1$ was then digested with $\mathrm{Xbal}$ and Spel restriction enzymes to remove the DNA fragment $+136-193$. Religation resulted in the generation of the $\mathrm{pb}_{2} \Delta 19(167)$ construction

\section{Expression in E. coli and Purification of $b_{2}$-DHFR} Fusion Proteins

\section{Cloning of DNA Encoding $b_{2}(167)-D H F R$ and $b_{2} \Delta 19(167)-D H F R$} into Expression Vector pUHE

For cloning into the expression vector pUHE, the DNA fragments contained in the pGEM4 plasmids encoding the fusion proteins $b_{2}(167)$ DHFR and $b_{2} \Delta 19(167)$-DHFR, respectively, were modified by introduction of an $\mathrm{Ncol}$ site at position -2 and by changing the methionine codon at position 86 to an isoleucine codon by in vitro mutagenesis. The Ncol-Hindlll fragments were removed from the recombinant pGEM4 plasmids and were introduced into a Ncol-Hindlll-linearized pUHE vector resulting in the recombinant plasmids pUHE 60 (encoding $b_{2}$ (167)-DHFR) and pUHE 73 (encoding $b_{2} \Delta 19$ (167)-DHFR).

\section{Expression of $b_{2}(167)-D H F R$ and $b_{2} \Delta 19(167)-D H F R$}

\section{in E. coll Strain BMH71.18}

For IPTG-dependent expression, E. coli cells transformed with pUHE60 and pUHE73, respectively, were grown overnight at $37^{\circ} \mathrm{C}$ in LB medium ( $1 \%[\mathrm{w} / \mathrm{v}]$ tryptone, $0.5 \%[\mathrm{w} / \mathrm{v}]$ yeast extract, $0.5 \%[\mathrm{w} / \mathrm{v}]$ $\mathrm{NaCl}$ ) supplemented with $100 \mu \mathrm{g} / \mathrm{ml}$ ampicillin. The cultures were diluted 1000 -fold in fresh LB medium containing ampicillin and were grown at $37^{\circ} \mathrm{C}$ to an $O D_{585} 0.5$. Expression was induced by addition of $1 \mathrm{mM}$ IPTG and incubation for $1 \mathrm{hr}$ at $37^{\circ} \mathrm{C}$.

\section{Purification of Inclusion Bodies}

Cells were harvested by centrifugation and were resuspended at $2 \mathrm{ml}$ $100 \mathrm{ml}$ of the original volume in buffer A $(25 \%[\mathrm{~W} / \mathrm{V}]$ sucrose, $50 \mathrm{mM}$ Tris-HCl [pH 8.0]). Lysozyme was added to $1 \mathrm{mg} / \mathrm{ml}$, and the cell suspension was incubated under gentle shaking for $10 \mathrm{~min}$ at room temperature. Afterwards, the suspension was adjusted to the volume of the original culture adding buffer A containing $25 \mathrm{mM}$ EDTA, $10 \mathrm{mM}$ dithiothreitol (DTT), $1 \mathrm{mM}$ phenylmethylsulfonyl fluoride (PMSF), and $2 \%$ Triton $X-100$. Cells were broken by sonication using a tip sonicator
(Branson sonifier, $40 \%$ duty, setting 7,3 310 pulses). Inclusion bodies were collected by centrifugation $\left(30 \mathrm{~min}\right.$ at $\left.50,000 \times \mathrm{g}, 4^{\circ} \mathrm{C}\right)$, and the resulting pellets were successively washed by sonication and centrifugation in buffer $\mathrm{B}$ (20 mM Tris-HCl [pH 7.4], $1 \mathrm{mM}$ EDTA, $1 \mathrm{mM}$ PMSF, $50 \mathrm{mM}$ DTT) containing $1 \%$ Triton $X-100$, buffer $B$ containing $0.1 \%$ Triton $X-100$, and buffer $B$ alone. Finally the pellets were resuspended in guanidinium buffer $(6 \mathrm{M}$ guanidinium- $\mathrm{HCl}, 50 \mathrm{mM} \mathrm{DTT}, 20 \mathrm{mM}$ Tris$\mathrm{HCL}[\mathrm{pH} 7.4])$ and stored at $-80^{\circ} \mathrm{C}$.

Import of Precursor Proteins into Isolated Mitochondria Wild-type Saccharomyces cerevisiae (strain MC3:YIPGALOTC; Pollock et al., 1988) and mutant strain mif4 were grown overnight in YPEG medium and were harvested at an $O D_{578}$ of 1-1.5. Mitochondria were isolated as described (Daum et al., 1982; Hartl et al., 1987). In brief, spheroplasts were prepared by zymolyase treatment and were homogenized in $0.6 \mathrm{M}$ sorbitol, $10 \mathrm{mM}$ Tris- $\mathrm{HCl}, 0.5 \%$ bovine serum albumin (BSA), 1 mM PMSF (pH 7.4) by 10 strokes in a Dounce homogenizer at $0^{\circ} \mathrm{C}$. Mitochondria were purified by differential centrifugation and were finally resuspended in SEM buffer ( $250 \mathrm{mM}$ sucrose, $1 \mathrm{mM}$ EDTA and $10 \mathrm{mM}$ 3-[N-morpholino] propanesulfonic acid [MOPS] [pH 7.2]) at a protein concentration of $10 \mathrm{mg} / \mathrm{ml}$.

Precursor proteins were synthesized in the presence of [ $\left.{ }^{35} \mathrm{~S}\right]$ methionine by coupled transcription/translation in reticulocyte lysates (Stüber et al., 1984; Krieg and Melton, 1984; Pelham and Jackson, 1976). Postribosomal supernatants of reticulocyte lysates used in the import reactions were prepared and supplemented as described (Zimmermann and Neupert, 1980). Import mixtures usually contained $1.5 \mathrm{mM}$ DTT, 2 mM NADH, and 10\% reticulocyte lysate in BSA medium (3\% BSA, $220 \mathrm{mM}$ sucrose, $80 \mathrm{mM} \mathrm{KCl}$, and $10 \mathrm{mM} \mathrm{MOPS} / \mathrm{KOH}$ [pH 7.2]). ATP was added at $0-2 \mathrm{mM}$. The final concentration of mitochondria in the import reaction was $0.5 \mathrm{mg} / \mathrm{ml}$. Incubation for import was carried out at $25^{\circ} \mathrm{C}$ for various times. Inhibition of the membrane potential and protease treatment of mitochondria after import were performed as published (Hartl et al., 1986; Rassow et al., 1989).

Precursor proteins were precipitated from reticulocyte lysate with ammonium sulfate ( $66 \%$ saturation) for $30 \mathrm{~min}$ at $0^{\circ} \mathrm{C}$, pelleted by centrifugation, and dissolved in $8 \mathrm{M}$ urea, $20 \mathrm{mM}$ HEPES, $100 \mathrm{mM}$ $\mathrm{DTT}$ ( $\mathrm{pH} \mathrm{7.4).} \mathrm{For} \mathrm{import,} \mathrm{urea-denatured} \mathrm{precursor} \mathrm{was} \mathrm{diluted} \mathrm{20-} \mathrm{to}$ 40 -fold at $25^{\circ} \mathrm{C}$ into SM buffer (250 $\mathrm{mM}$ sucrose, $10 \mathrm{mM} \mathrm{MOPS} / \mathrm{KOH}$, [pH 7.2]) containing $0.4 \mathrm{mg} / \mathrm{ml}$ isolated mitochondria. Amounts of urea-denatured precursor employed were equivalent to those used in experiments with nondenatured protein. Nondenatured lysate was omitted from reactions containing denatured precursor. When indicated, the SM buffer was supplemented with $80 \mathrm{mM} \mathrm{KCl}, 2.5 \mathrm{mM}$ MgOAc, $2 \mathrm{mM} \mathrm{NADH}$, and $2 \mathrm{mM}$ ATP.

\section{Subfractionation of Mitochondria}

Mitoplasts were prepared by osmotic shock treatment of mitochondria essentially as described (Daum et al., 1982; Hartl et al., 1987). In brief, mitochondria were reisolated after import by centrifugation and were resuspended in fresh SEM buffer at a protein concentration of $20 \mathrm{mg} /$ $\mathrm{ml}$. The mitochondrial suspension was divided into aliquots and diluted 40-fold either in SEM buffer or in $10 \mathrm{mM} \mathrm{HEPES}(\mathrm{pH} \mathrm{7.4)}$ and incubated for $15 \mathrm{~min}$ at $0^{\circ} \mathrm{C}$. Afterwards, each reaction was adjusted to $250 \mathrm{mM}$ sucrose and $150 \mathrm{mM} \mathrm{KCl}$ and was divided into aliquots corresponding to $40 \mu \mathrm{g}$ of mitochondrial protein for treatment with PK $(15 \mu \mathrm{g} / \mathrm{ml}$ final concentration) and for enzymatic measurement of cytochrome $b_{2}$ activity (Appleby and Morton, 1959).

Soluble mitochondrial protein was extracted by digitonin as described (Ostermann et al., 1989). Following incubation for import, mitochondria were reisolated by centrifugation and resuspended in SEM buffer and $100 \mathrm{mM} \mathrm{KCl}$ at a protein concentration of $10 \mathrm{mg} / \mathrm{ml}$. The suspension was mixed with an equal volume of $0.7 \%$ digitonin (dissolved in SEM buffer with $\mathrm{KCl}$ ) and incubated for $2 \mathrm{~min}$ at $0^{\circ} \mathrm{C}$. Membranes and insoluble material was centrifuged for $10 \mathrm{~min}$ at $15,000 \times$ $\mathrm{g}$, and the supernantant was used for further analysis.

\section{Miscellaneous}

The following procedures were carried out according to published methods. groEL and groES were purified from a groE-overproducing strain of $E$. coli harboring the plasmid pOF39 (Fayet et al., 1986; Martin et al., 1991). Trichloroacetic acid (TCA) precipitation (Bensadoun and 
Weinstein, 1976), protein determination (Bradford, 1976), immunoprecipitation of cytochrome $b_{2}$ and DHFR (Hartl et al., 1986), SDS-PAGE (Lämmli, 1970), nondenaturing PAGE (Musgrove ot al., 1987; Ostermann et al., 1989), electrotransfer to nitrocellulose filters (Towbin et al., 1979), immunolabeling and visualization of bound antibodies (Blake et al., 1984), fluorography, quantification of fluorographs and of immunostained Western blots (Hartl et al., 1986; Magiewicz and Knight, 1988).

\section{Acknowledgments}

The authors appreciate the expert technical assistance of Susanne Neumahr. This work was supported by the Deutsche Forschungsgemeinschaft (SFB 184, B2).

The costs of publication of this article were defrayed in part by the payment of page charges. This article must therefore be hereby marked "advertisement" in accordance with 18 USC Section 1734 solely to indicate this fact.

Received June 19, 1991; revised January 6, 1992

\section{References}

Appleby, C. A., and Morton, R. K. (1959). Lactic dehydrogenase and cytochrome $b_{2}$ of baker's yeast. Purification and crystallization. Biochem. J. 71, 492-499.

Attardi, G., and Schatz, G. (1988). The biogenesis of mitochondria. Annu. Rev. Cell Biol 4, 289-333.

Behrens, M., Michaelis, G., and Pratje, E. (1991). Mitochondrial inner membrane protease 1 of Saccharomyces cerevisiae shows sequence similarity to the Escherichia coli leader peptidase. Mol. Gen. Genet. 228, 167-176.

Bensadoun, A., and Weinstein, D. (1976). Assay of proteins in the presence of interfering materials. Anal. Biochem. 70, 241-250.

Blake, M. S., Johurta, K. H., Russell-Jones, G. J., and Gotschlich, E. C. (1984). A rapid, sensitive method for detection of alkaline phosphatase-conjugated anti-antibodies on Western blots. Anal. Biochem. 136, 175-179.

Bochkareva, E. S., Lissin, N. M., and Girshovich, A. S. (1988). Transient association of newly-synthesized unfolded proteins with the heat-shock groEL protein. Nature 336, 254-257.

Böhni, P., Gasser, S., Leaver, C., and Schatz, G. (1980). A matrixlocalized mitochondrial protease processing cytoplasmically made precursors to mitochondrial proteins. In The Organisation and Expression of the Mitochondrial Genome, A. M. Kroon and C. Saccone, eds. (Amsterdam: Elsevier/North- Holland), pp. 423-433.

Bradford, M. M. (1976). A rapid and sensitive method for the quantification of microgram quantities of protein utilizing the principle of protein dye binding. Anal. Biochem. 72, 248-254.

Chandrasekhar, G. N., Tilly, K., Woolford, C., Hendrix, R., and Georgopoulos, C. (1986). Purification and properties of the groES morphogenetic protein of Escherichia coli. J. Biol. Chem. 261, 12414-12419.

Cheng, M. Y., Hartl, F.-U., Martin, J., Pollock, R. A., Kalousek, F., Neupert, W., Hallberg, E. M., Hallberg, R. L., and Honwich, A. L. (1989). Mitochondrial heat-shock protein hsp60 is essential for assembly of proteins imported into yeast mitochondria. Nature 337, 620-625.

Cheng, M. Y., Hartl, F.-U., and Horwich, A. L. (1990). The mitochondrial chaperonin hsp60 is required for its own assembly. Nature 348, 455458.

Daum, G., Böhni, P. C., and Schatz, G. (1982). Import of proteins into mitochondria: cytochrome $b_{2}$ and cytochrome $c$ peroxidase are located in the intermembrane space of yeast mitochondria. J. Biol. Chem. 267, 13028-13033.

Fayet, O., Louran, J. M., and Georgopoulos, C. (1986). Suppression of the Escherichia coli dnaA46 mutation by amplification of the groES and groEL genes. Mol. Gen. Genet. 202, 435-445.

Guiard, B. (1985). Structure, expression and regulation of a nuclear gene encoding a mitochondrial protein: the yeast $L(+)-$ lactate cytochrome $c$ oxidoreductase (cytochrome $b_{2}$ ). EMBO J. 4, 3265-3272.

Hallermayer, G., Zimmermann, R., and Neupert, W. (1977). Kinetic studies on the transport of cytoplasmically synthesized proteins into mitochondria in intact cells of Neurospora crassa. Eur. J. Biochem. 81, 523-532.

Hartl, F.-U., and Neupert, W. (1990). Protein sorting to mitochondria: evolutionary conservations of folding and assembly. Science 247 , 930-938

Hartl, F.-U., Schmidt, B., Wachter, E., Weiss, H., and Neupert, W. (1986). Transport into mitochondria and intramitochondrial sorting of the $\mathrm{Fe} / \mathrm{S}$ protein of ubiquinol-cytochrome $c$ reductase. Cell $47,939-$ 951.

Hartl, F.-U., Ostermann, J., Guiard, B., and Neupert, W. (1987). Successive translocation into and out of the mitochondrial matrix: targeting of proteins to the intermembrane space by a bipartite signal peptide. Cell 51, 1027-1037.

Hartl, F.-U., Pianner, N., Nicholson, D. W., and Neupert, W. (1989). Mitochondrial protein import. Biochim. Biophys. Acta 998, 1-45.

Hartl, F.-U., Lecker, S., Schiebel, E., Hendrick, J. P., and Wickner, W. (1990). The binding cascade of SecB to SecA to SecY/E mediates preprotein targeting to the E. coli plasma membrane. Cell $63,269-$ 279 .

Hawlitschek, G., Schneider, H., Schmidt, B., Tropschug, M., Hartl, F.-U., and Neupert, W. (1988). Mitochondrial protein import: identification of processing peptidase and of PEP, a processing enhancing protein. Cell 53, 795-806.

Hemmingsen, S. M., Woolford, C., van der Vies, S. M., Tilly, K., Dennis, T. D., Georgopoulos, C. P., Hendrix, A. W., and Ellis, A. J. (1988). Homologous plant and bacterial proteins chaperone oligomeric protein assembly. Nature 333, 330-334.

Hurt, E. C., and van Loon, A. P. G. M. (1986). How proteins find mitochondria and intramitochondrial compartments. Trends Biochem. Sci. 11, 204-207.

Kang, P.J., Ostermann, J., Shilling, J., Neupert, W., Craig, E. A., and Pfanner, N. (1990). Requirement for hsp70 in the mitochondrial matrix for translocation and folding of precursor proteins. Nature 348, 137142.

Krieg, P. A., and Melton, D. A. (1984). Functional messenger RNAs are produced by SP6 in vitro transcription of cloned cDNAs. Nucl. Acids Res. 12, 7057-7070.

Kusakawa, N., Yura, T., Uequichi, C., Akiyama, Y., and Ito, K. (1989). Effects of mutations in heat-shock genes groES and groEL on protein export in Escherichia coli. EMBO J. 8, 3517-3512.

Laminet, A. A., and Plückthun, A. (1989). The precursor of $\beta$-lactamase: purification, properties and folding kinetics. EMBO J. 8, 14691477.

Lämmli, V. K. (1970). Cleavage of structural proteins during the assembly of the head bacteriopage T4. Nature 227, 680-685.

Landry, S. J., and Gierasch, L. M. (1991). The chaperonin groEL binds a polypeptide in an $\alpha$-helical conformation. Biochemistry $30,7359-$ 7362.

Lecker, S., Lill, R., Ziegelhoffer, T., Bassford, P. J., Jr, Kumamoto, C. A., and Wickner, W. (1989). Three pure chaperone proteins of Escherichia coli, SecB, trigger factor, and GroEL, form soluble complexes with precursor proteins in vitro. EMBO J. 8, 2703-2709.

Liu, G., Topping, T. B., and Randall, L. L. (1989). Physiological role during export for the retardation of folding by the leader peptide of maltose-binding protein. Proc. Natl. Acad. Sci. USA 86, 9213-9217.

Lubben, T. H., Gatenby, A. A., Donaldson, G. K., Lorimer, G. H., and Vittanen, P. V. (1990). Identification of a groES-like chaperonin in mitochondria which facilitates protein folding. Proc. Natl. Acad. Sci. USA 87, 7683-7687.

Magiewicz, R. A., and Knight, P. J. (1988). Transmission densitometry of stained nitrocellulose paper. Anal. Biochem. 175, 85-90.

Mahlke, K., Pfanner, N., Horwich, A. L., Hartl, F.-U., and Neupert, W. (1990). Sorting pathways of mitochondrial inner membrane proteins. Eur. J. Biochem. 192, 551-555.

Martin, J., Langer, T., Boteva, R., Schramel, A., Horwich, A. L., and Hartl, F.-U. (1991). Chaperonin-mediated protein folding at the surface of groEL through a "molten globule"-like intermediate. Nature 352, 3642. 
Musgrove, J. E., Johnson, R. A., and Ellis, R. J. (1987). Dissociation of the ribulosebisphosphate-carboxlase large-subunit binding protein into dissimilar subunits. Eur. J. Biochem. 163, 529-534.

Ostermann, J., Horwich, A. L., Neupert, W., and Hartl, F.-U. (1989) Protein folding in mitochondria requires complex formation with hsp60 and ATP hydrolysis. Nature, 341, 125-130.

Ostermann, J., Voos, W., Kang, P. J., Craig, E. A., Neupert, W., and Pfanner, N. (1990). Precursor proteins in transit through mitochondrial contact sites interact with hsp70 in the matrix. FEBS Lett. 277, 281284.

Pauling, L., and Corey, R. B. (1951). Configurations of polypetide chains with favored orientations around single bonds: Iwo new pleated sheets. Proc. Natl. Acad. Sci. USA 37, 729-740.

Pelham, H. R. B., and Jackson, R. J. (1976). An efficient mRNAdependent translation system from reticulocyte lysates. Eur. J. Biochem. 67, 247-256.

Philips, G. J., and Silhavy, T. J. (1990). Heat-shock proteins DnaK and GroEL faciliate export of LacZ hybrid proteins in E. coli. Nature 344, 88:2-884

Pollock, R. A., Hartl, F.-U., Cheng, M. Y., Ostermann J., Horwich, A., and Neupert, $W$. (1988). The processing peptidase of yeast mitochondria: the two co-operating components MPP and PEP are structurally related. EMBO J. 7, 3493-3500.

Randall, L. L., and Hardy, J. S. (1989). Unity in function in the absence of consensus in sequence: role of leader peptides in export. Science 243, 1156-1159

Rassow, J., Guiard, B., Wienhues, U., Herzog, V., Hartl, F.-U., and Neupert, W. (1989). Translocation arrest by reversible folding of a precursor protein imported into mitochondria: a means to quantitate translocation contact sites. J. Cell Biol. 109, 1421-1428.

Rassow, J., Hartl, F.-U., Guiard, B., Pfanner, N., and Neupert, W (1990). Polypeptides traverse the mitochondrial envelope in an extended state. FEBS Lett. 275, 190-194.

Rerading, D. S., Hallberg, R. L., and Myers, A. M. (1989). Characterization of the yeast HSP60 gene coding for a mitochondrial assembly factor. Nature 337, 655-659.

Scherer, P. E., Krieg, U. C., Hwang, S. T., Vestweber, D., and Schatz, $G$. (1990). A precursor protein partly translocated into yeast mitochondria is bound to a $70 \mathrm{kd}$ mitochondrial stress protein. EMBO J. 9, 43154322.

Schleyer, M., and Neupert, W. (1985). Transport of proteins into mitochondria: translocation intermediates spanning contact sites between outer and inner membranes. Cell 43, 339-350.

Schmidt, B., Wachter, E., Sebald, W., and Neupert, W. (1984). Processing peptidase of Neurospora mitochondrla: two-step cleavage of imported ATPase subunit 9. Eur. J. Biochem. 144, 581-588.

Schneider, A., Behrens, M., Scherer, P., Pratje, E., Michaelis, G., and Schatz, G. (1991). Inner membrane protease I, an enzyme mediating intramitochondrial protein sorting in yeast. EMBO J. 10, 247-254

Schwaiger, M., Herzog, V., and Neupert, W. (1987). Characterization of translocation contact sites involved in the import of mitochondrial proteins. J. Cell. Biol. 105, 235-246.

Stuart, R. A., Nicholson, D. W. Wienhues, U., and Neupert, W. (1990) Import of apocytochrome $c$ into the mitochondrial intermembrane space along a cytochrome $c_{1}$ sorting pathway. J. Biol. Chem. 265 , 20210-20219.

Stüber, D., Ibrahimi, I., Culter, D., Dobberstein, B., and Bujard, H. (1984). A novel in vitro transcription-translation system: accurate and efficient synthesis of single proteins from cloned DNA sequences. EMBO. J. 3, 3143-3148.

Towbin, H., Staehelin, T., and Gordon, J. (1979). Electrophoretic transfer of proteins from polyacrylamide geis to nitrocellulose sheets: procedure and some applications. Proc. Natl. Acad. Sci. USA 79, 267-271. Vestweber, D., and Schatz, G. (1988). A chimeric mitochondrial precursor protein with internal disulfide bridges blocks import of authentic precursors into mitochondria and allows quantification of import sites. J. Cell Biol. 107, 2037-2043.

Van Loon, A. P. G. M., and Schatz, G. (1987). Transport of proteins to the mitochondrial intermembrane space: the 'sorting' domain of the cytochrome $c_{1}$ presequence is a stop-transfer sequence specific for the mitochondrial inner membrane. EMBO J. 6, 2441-2448.

Van Loon, A. P. G. M., Brändli, A. W., and Schatz, G. (1986). The presequences of two imported mitochondrial proteins contain information for intracellular and intramitochondrial sorting. Cell 44, 801-812. Van Loon, A. P. G. M., Brändli, A. W., Pesold-Hurt, B., Blank, D., and Schatz, G. (1987). Transport of proteins to the mitochondrial intermembrane space: The 'matrix targeting' and the 'sorting' domains in the cytochrome $c_{1}$ presequence. EMBO J. 6, 2433-2439.

Viitanen, P. V., Lubben, T. H., Reed, J., Goloubinoff, P., O'Keefe, D. P., and Lorimer, G. (1990). Chaperonin-facilitated refolding of ribonucleosebisphosphate carboxylase and ATP hydrolysis by chaperonin 60 (groEL) are $\mathrm{K}^{+}$dependent. Biochemistry 29, 5665-5671.

von Heijne, G. (1988). Transcending the impenetrable: how proteins come to terms with membranes. Blochim. Blophys. Acta 947, 307333.

Zimmermann, R., and Neupert, W. (1980). Transport of proteins into mitochondria: posttranslational transfer of ADP/ATP carrier into mitochondria. Eur. J. Biochem. 109, 217-229. 